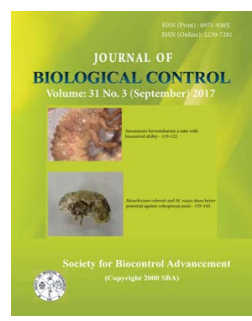

\title{
Report of mite, Sancassania karnatakaensis (Krishna Rao \& Ranganath, 1982) as a potential bioagent of white grub species, Lepidiota mansueta Burmeister with taxonomic notes
}

\author{
K. SREEDEVI ${ }^{*}$, PRATIBHA MENON and SUNIL RATHOD \\ Division of Entomology, ICAR-Indian Agricultural Research Institute, New Delhi-110 012 \\ *Corresponding author E-mail: kolla.sreedevi@gmail.com
}

\begin{abstract}
White grubs are the major pests of several commercial crops viz., groundnut, sugarcane, potato, maize, arecanut, etc. During surveys carried out in sugarcane fields of western Uttar Pradesh for white grub larval collection, it was observed that larvae of Lepidiota mansueta Burmeister (Coleoptera: Scarabaeidae) collected from sugarcane fields of Jallopur village, Amroha district, Uttar Pradesh, India exhibited the occurrence of mites on their bodies. The mites were identified as Tyrophagous putriscentiae, Ryzoglyphus sp. and Sancassania karnatakaensis, of which the predominant species was S. karnatakaensis. Subsequently studies were conducted to observe the occurrence of S. karnatakaensis on reared larvae of five major white grub species viz., Holotrichia nagpurensis Khan and Ghai, Anomala bengalensis (Blanchard), Anomala dimidiata (Hope), Maladera insanabilis (Brenske) and Lepidiota mansueta Burmeister in the laboratory. The colonization of mite $S$. karnatakaensis was observed on all five species with variations in the percent occurrence. The mite colonization was high in L. mansueta, which gradually led to $98 \%$ mortality, indicating the potentiality of mite as biocontrol agent.
\end{abstract}

KEY WORDS: Mite, mortality, Lepidiota mansueta, Sancassania karnatakaensis, white grub

(Article chronicle: Received: 14-07-2017; Revised: 26-09-2017; Accepted: 30-09-2017)

\section{INTRODUCTION}

White grubs are ubiquitous and serious pests of several crops and termed as national pest. These primarily belong to the subfamilies Melolonthinae and Rutelinae of Scarabaeidae (Coleoptera). They are the subterranean pests, where the larvae feed on the roots and rootlets of the crop and lead to drying and subsequent dying of the plants. The white grubs infest sugarcane, maize, groundnut, soybean, potato, turmeric, ginger, arecanut, etc. Their damage is more pronounced in sugarcane crop resulting in huge losses sometimes as high as $80-100 \%$ (Chelvi et al., 2011). The management of the white grubs is becoming herculean task due to its subterranean nature and high fecundity.

During the surveys carried out in sugarcane fields at Jallopur village, Amroha district of western Uttar Pradesh, India for the larval collection, it was found that larval bodies were deposited with mites. So, a study has been carried out to assess the efficacy of mites on white grub larvae as a biocontrol agent.

\section{MATERIALS AND METHODS}

The larvae of white grubs were collected from the sugarcane fields of Jallopur village, Amroha district (28 $54^{\prime} \mathrm{N}$; 7831'E), western Uttar Pradesh, India during 2013-14. The larvae were collected carefully by digging the soil in sugarcane fields. The collected larvae were transferred to plastic jars and brought to the laboratory at Division of Entomology, IARI, New Delhi for further studies. The larvae were reared on potato pieces in the moist soil for taxonomic categorization. Based on the personal studies on larval taxonomic characters coupled with confirmation by mt CO1 molecular characterization, the larvae were identified upto species level and maintained rearing species wise. The grubs of Lepidiota mansueta Burmeister, a biennial white grub species was found to be abundant and predominant. The mites present on the larval bodies of white grubs were carefully removed and examined for species identity. Taxonomic studies were carried out on the abundant mite species, Sancassania karnatakaensis (Krishna Rao \& Ranganath, 1982). 


\section{Taxonomic studies}

The mites were picked from the body of the grub of Lepidiota mansueta Burmeister using a brush under Leica MZ6 stereozoom microscope. The mites were mounted in Hoyer's medium and labeled. After drying on hot plate at 55-60 ${ }^{\circ} \mathrm{C}$ for 3-5 days, the slides were observed under Leica DM 2000 phase contrast microscope.

The S. karnatakaensis was adequately described by Krishna Rao \& Ranganath et al. (1982) on Holotrichia sp. However, the morphometrics were missing in their descriptions and since the genus Caloglyphus was transferred to Sancassania, characters that describe them were studied and documented.

All measurements were made from slide-mounted specimens using stage-calibrated ocular micrometers on a phase contrast microscope. Chelicerae were measured from the basal articulations to the tips of movable digits. Idiosomal lengths were measured from the anterior margin to the posterior margin. All measurements are given in micrometers $(\mu \mathrm{m})$ and denote length unless specified. The terminology follows that of Griffiths et al. (1990).

\section{Infestation studies}

Later the adults of $S$. karnatakaensis (10 pairs) were released on to the grubs of five major species, Holotrichia nagpurensis Khan and Ghai, Anomala bengalensis (Blanchard), Anomala dimidiata (Hope), Maladera insanabilis (Brenske) and Lepidiota mansueta Burmeister to observe the colonization and multiplication in the laboratory. The larvae were daily observed for the counts of mites on their bodies till pupation. The percent infestation of mite, S. karnatakaensis was calculated. The mortality of grubs was also documented.

\section{Results}

The mites extracted from white grub larval bodies collected from Jallopur, Amroha, U.P. revealed three species, Tyrophagous putrescentiae (Schrank), Rhizoglyphus sp. and Sancassania (=Caloglyphus) karnatakaensis (Krishna Rao and Ranganath, 1982) (Acari: Acaridae). However, the first two species were very less in number and the latter, $S$. karnatakaensis was higher in number ranging from 400 to 1200 per grub of the predominant species, Lepidiota mansueta Burmeister.

\section{Taxonomic studies of the mite, Sancassania karnatakaensis}

The morphometrics of Sancassania karnatakaensis is herewith furnished for the first time that adds to the available descriptions.

\section{Redescription of Sancassania karnatakaensis (Krishna Rao \& Ranganath, 1982)}

Body smooth, colourless and shining; appendages pale brown.

Male (homomorphic) $(\mathrm{n}=10)$ : Length $585 \pm 61$ (525$700)$; width $333 \pm 65$ (275-420); chelicerae $133 \pm 21$ (100$160)$.

Dorsum: Propodosomal shield oblong with concave lateral borders; posterior border not distinctly ' $\mathrm{M}$ ' shaped. All setae smooth, vi short, arising midway on the lateral borders of poropodosomal shield, Length of dorsal setae: vi $62 \pm 7$ (50-73), ve 9 \pm 3 (7-13), sce $227 \pm 57$ (140-300), sci $43 \pm 11$ (30-60), c $31 \pm 9$ (23-50), d 79 22 (65-125), $e_{1} 147 \pm 44(100-225), h_{1} 195 \pm 85$ (75-300), c $c_{2} 35 \pm 10$ (25$50), c p 156 \pm 26$ (120-200), $d_{2} 44 \pm 10$ (33-55), e $103 \pm 22$ (75-143), sae 139 \pm 41 (65-200), sai 266 \pm 82 (175-375), supracoxal setae $s c x 7 \pm 3(5-10)$, represented by a small thorn like structure.

Venter: $p a_{1} 74 \pm 35$ (50-150), $p a_{2} 41 \pm 18$ (30-80), $p a_{3}$ $19 \pm 10(10-40)$.

Female $(n=10)$ : Length $738 \pm 63$ (640-800); width $446 \pm 68$ (365-540); chelicerae 156 \pm 7 (150-165).

Dorsum: Propodosomal shield oblong with concave lateral borders; posterior border not distinctly ' $M$ ' shaped. All setae smooth, vi short, arising midway on the lateral borders of propodosomal shield, vi $80 \pm 11$ (65-100), ve $8 \pm 2$ (6-10), sce $253 \pm 34$ (215-310), sci 44 \pm 7 (35-55), c c $32 \pm 7$ (20-40), d $79 \pm 25$ (40-110), e $108 \pm 20$ (70-135), $h_{1} 82 \pm 13$ (65-100), c $c_{2} 40 \pm 8(25-50), c p 181 \pm 19$ (150-200), $d_{2} 49 \pm 12$ (30-60), e $296 \pm 21$ (50-125), sae 153 \pm 34 (100-200), sai $114 \pm 23$ (75-140), supracoxal setae $s c x 7 \pm 3$ (5-10), represented by a small thorn like structure. $(15-25)$.

Venter: $p a_{1} 20 \pm 4$ (15-25), $p a_{2} 23 \pm 3(20-25), p a_{3} 20 \pm 4$

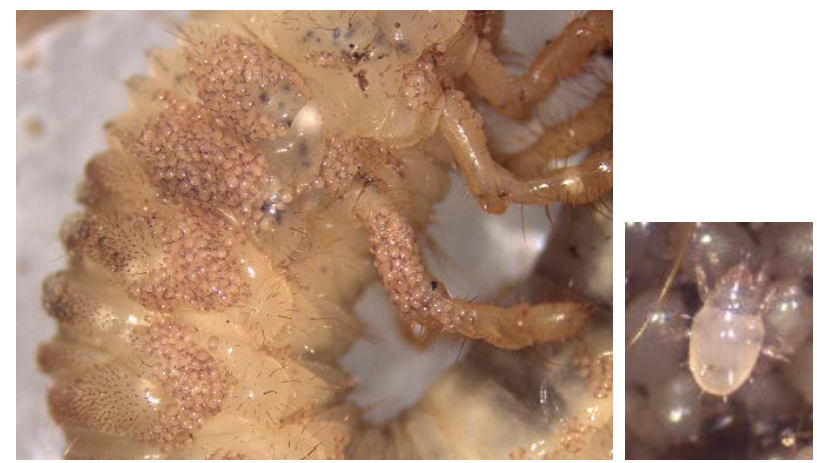

Fig. 1. A - Sancassania karnatakaensis on Lepidiota mansueta, B - mite. 


\section{Infestation of Sancassania karnatakaensis}

Studies on the mite colonization on five white grub species, Holotrichia nagpurensis Khan and Ghai, Anomala bengalensis (Blanchard), Anomala dimidiata (Hope), Maladera insanabilis (Brenske) and Lepidiota mansueta Burmeister revealed that the mite established on grubs of all five species with varied infestation. The less infestation ranging from 12 to $28 \%$ was observed on $H$. nagpurensis, A. dimidiata, $M$. insanabilis and $A$. bengalensis while the highest was on L. mansueta (95\%). The percent mortality was less in $H$. nagpurensis (9\%), A. dimidata (10\%), $M$. insanabilis (11\%) and A. bengalensis (21\%) ranging from 9 to $21 \%$ while it was high in L. mansueta (98\%) (Table 1).

Table 1. Infestation of Sancassania karnatakensis on white grub species

\begin{tabular}{|l|l|l|}
\hline White grub species & $\begin{array}{l}\text { Per cent } \\
\text { infestation }\end{array}$ & $\begin{array}{l}\text { Per cent } \\
\text { mortality }\end{array}$ \\
\hline Holotrichia nagpurensis & 12 & 09 \\
\hline Anomala dimidata & 17 & 10 \\
\hline Maladera insanabilis & 19 & 11 \\
\hline Anomala bengalensis & 28 & 21 \\
\hline Lepidiota mansueta & 92 & 98 \\
\hline
\end{tabular}

\section{DISCUSSION}

Several groups of mites are observed to commonly associate with scarabs, especially species of white grubs belonging to Melolonthinae, Rutelinae and Dynastinae. These can be found associated with the larvae, where they may feed on cuticular exudates or as predators of nematodes or other mites, or fungivores. Sancassania karnatakaensis was predominant among the three mite species observed on white grub larvae or grubs in present study. The T. putrescentiae and Rhizoglyphus sp. are the mould and bulb mites, respectively that dwell in the soil, where former feeds on moulds and latter on bulbs and roots of the plants. Their presence or occurrence on the white grub larvae may be occasional, but the mite $S$. karnatakaensis was found to colonise and multiply on the white grub larva. Most of the species of Sancassania (= Caloglyphus) are scarab associates mainly phoretic.

The genus Sancassania was erected by Oudemans in 1916 with $S$. chelone Oudemans 1916 as its type species. Berlese in 1923, erected the subgenus Caloglyphus which was synonymised with Sancassania by Samsinak (1960). In 1980, Samsinak based on both adult and hypopial characters revised the tribe Caloglyphini and elevated and re-established the status of Caloglyphus to genus. Rao et al. (1982) also opined that based on available information it was difficult to co-relate the adult and hypopial characters at the generic level, hence agreed with Samsinak and deemed it best to merge all genera under Caloglyphus. However, Klimov (2000) revised acarid mites of tribe Caloglyphini and synonymized Caloglyphus with Sancassania and this is currently being followed.

Sancassania is known as a phoretic or saprophage or necrophage of beetles that feeds on dead hosts (OConnor, 1982), where they attach to an insect, wait until it dies and then consume the dead insect. But in present study, $S$. karnatakaensis was found to associate with the live larvae and complete all developmental stages on the white grub, L. mansueta grub. Chmielewski \& Lipa. (1967) reported association of Sancassania (= Caloglyphus) with scarab species. Sancassania polyphyllae (Acari: Acaridae) was reported to be associated with larvae of the white grub, Polyphylla fullo by Ipek Ekmen et al. (2010a) and S. polyphyllae was reported to feed on the tissues of $P$. fullo (Ipek Ekmen et al., 2010b). David et al. (1986) reported that Sancassania sp. were predatory on eggs of the white grub, Holotrichia serrata F. causing mortality upto 96 per cent. So, $S$. karnatakaensis as a potent biocontrol agent on L. mansueta can be assessed further to contain the white grub species.

The mode of infectivity of mite causing larval mortality has to be ascertained. The proper identification of these mites and their association with white grub species will help us in strategizing the management options. The management of white grub species is becoming extremely tough due to their subterranean nature and also horizontal movement of the grubs. Since L. mansueta is a serious pest of sugarcane crop, the mite $S$. karnatakensis can become a potential bioagent for its containment in conjunction with the other compatible methods of management.

\section{ACKNOWLEDGEMENTS}

The authors are thankful to Barry M OConnor, Department of Ecology and Evolutionary Biology, University of Michigan, MI, US for kind help in ascertaining the genus Sancassania. Authors thank profusely the Director, Joint Director (Res.), ICAR-Indian Agricultural Research Institute, New Delhi and Head, Division of Entomology, IARI, New Delhi for facilitating the work. Thanks are also due to Dr. V. V. Ramamurthy, Retd. Principal Scientist, Division of Entomology, IARI, New Delhi for the support provided during the study.

\section{REFERENCES}

Chelvi TC, Richard Thilagaraj W, Nalini R. 2011. Field efficacy of formulations of microbial insecticide Metarhizium anisopliae (Hyphocreales: 
Clavicipitaceae) for the control of sugarcane white grub Holotrichia serrata F. (Coleoptera: Scarabaeidae). J Biopest. 4(2): 186-189.

Chmielewski W, Lipa JJ. 1967. Biological and ecological studies on Caloglyphus mite (Acarina: Acaridae) associated with Scarabaeidae. Acta Parasitologica Polonica 14(18): 179-186 + 4 plates.

David H, Nandagopal V, Ananthanarayana K. 1986. Recent studies on the control of white grub Holotrichia serrata Fabr. infesting sugarcane. J Soil Biol Ecol. 6(2): $117-127$

Griffiths DA, Atyeo WT, Norton RA, Lynch CA. 1990. The idiosomal chaetotaxy of astigmatid mites. J Zool. 220: 1-32. Crossref

Ipek Ekmen Z, Hazir S, Cakmak I, Ozer N, Karagoz M, . Kaya HK. 2010a. Potential negative effects on biological control by Sancassania polyphyllae (Acari: Acaridae) on an entomopathogenic nematode species. Biol Control 54(3):166-171. Crossref

Ipek Ekmen Z, Cakmak I, Karagoz M, Hazir S, Ozer N, Kaya HK. 2010b. Food preference of Sancassania polyphyllae (Acari: Acaridae): living entomopatho- genic nematodes or insect tissues? Biocontrol Sci Technol. 20(6): 553-566. Crossref

Klimov PB. A review of acarid mites of the tribe Caloglyphini (Acaridae, Acariformes) with description of a new genus and species from Siberia and Russian far east. Vestnik zoologii 34(4-5): 27-35.

OConnor BM. 1982. Evolutionary ecology of astigmatid mites. Annu Rev Entomol. 27: 385-409. Crossref

Oudemans AC. 1916. Acari verzamelt bij Bonn. Entomologishe Berichten 4: 261-266. Crossref

Rao NSK, Ranganath HR, ChannaBasavanna GP. 1982. Caloglyphus karnatakaensis sp. nov. (Acari: Acaridae) from India, with taxonomic comments on the genus Caloglyphus. Indian J Acarol. 7(1): 37-43.

Samsinak K. 1960. Ueber einige myrmekophile Milben aus der Familie Acaridae . as. esk Spol Entomol. 57: 185-192.

Samsinak K. 1980. Caloglyphus rodriguezi new species with taxonomic remarks on the tribe caloglyphini acari acaridae. Mitteilungen Aus Dem Zoologischen Museum Berlin, 201-206 